International Journal of Health Sciences
Available online at http://sciencescholar.us/journal/index.php/ijhs
Vol. 3 No. 3, December 2019, pages: $8 \sim 16$
e-ISSN: 2550-696X, p-ISSN: $2550-6978$
https://doi.org/10.29332/ijhs.v3n3.344

\title{
Effects of Health Promotion with Family Approaches on Blood Pressure and Headache toward Elderly
}<smiles>[14CH3]</smiles>

\author{
I Wayan Mustika a ${ }^{a}$ Ketut Sudiantara ${ }^{b}$
}

Article history: Received 18 May 2019, Accepted: 31 August 2019, Published: 15 October 2019

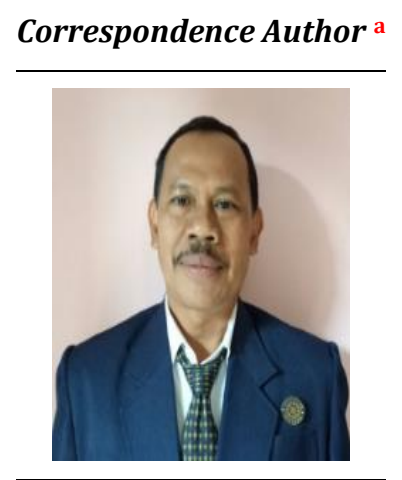

Keywords

family;

headache;

health promotion;

hypertension;

vasodilation;

\begin{abstract}
Hypertension caused damage to the brain's blood vessel endothelium. Resulting in platelet aggregation which was subsequently released by excessive serotonin and adrenergic hormones caused blood vessels vasoconstriction. The blood vessel constriction caused the intracranial blood supply to decrease. Resulting in ischemia was as an authority for cerebral vasodilation and headaches occurred. The elderly were the last life cycle stage for someone who was a risk with hypertension and headache. The study aimed at looking at the effect of health promotion with a family approach to lowering blood pressure and headaches for elderly. This research was an experimental study with a randomized pretest and posttest control group design (in the form of a community trial). The research was conducted for four months from June to September 2018 in Selemadeg Subdistrict, Tabanan. The sampling technique was random sampling. The sample number on the treatment group and control group were 590 people. Data analysis used the Mann-Whitney test and Wilcoxon sign rank test was a significance level of $p$-value $<0.05$. The results showed on the treatment group before and after the intervention was obtained the $p$-value $=0.0001$ on systolic and diastolic pressure data as well as the headache level. P-value $<0.05$ showed there were significant differences before and after health promotion with a family approach. The conclusion that there was an effect of health promotion with family approach to blood pressure and headache in the elderly. It was suggested the health workers promote more promotion of the healthy living community movement through health counseling and distributing brochures to the community including a balanced menu and exercise. Therefore, the healthy, productive, and prosperous elderly were realized.
\end{abstract}

e-ISSN: 2550-696X, p-ISSN: 2550-6978 ๑ Copyright 2019. The Author. SS Journals Published by Universidad Técnica de Manabí. This is an open-access article under the CC BY-SA 4.0 license (https://creativecommons.org/licenses/by-sa/4.0/) All rights reserved.

a Politeknik Kesehatan Denpasar, Bali, Indonesia

b Politeknik Kesehatan Denpasar, Bali, Indonesia 


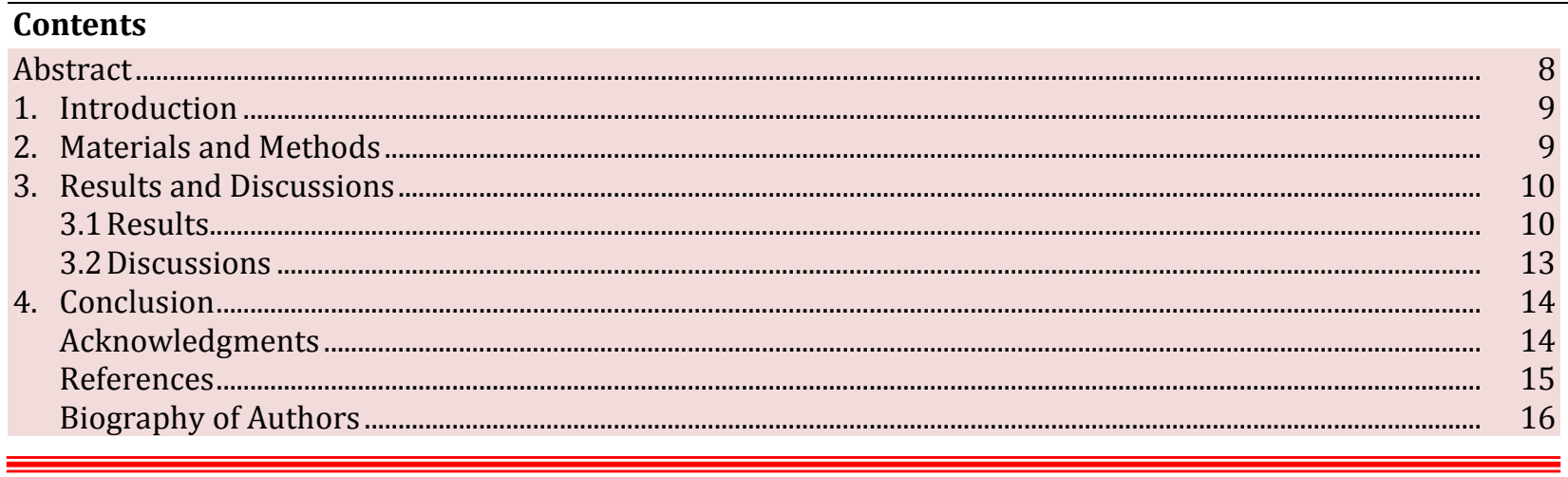

\section{Introduction}

Health promotion is essentially an activity or effort to convey health messages to the public, groups or individuals. Based on the message conveyed, it is expected the public, groups, or individuals can gain knowledge about better health. Knowledge is ultimately expected to influence behavior. The promotion is expected to have an effect on behavior change for the elderly.

The success of health promotion leading to educational goals achievement namely, behavior change is influenced by many factors including method factors, material factors or messages, educator officers who do them, and educational aids/teaching aids used. In order to achieve an optimal result, these factors must work together in harmony (Adnani et al., 2018; Sulaeman et al., 2018).

The family is the smallest unit of society, consisting of father, mother, and child. They are often called the nuclear family. Whereas, the family whose members include grandparents or grandmothers or other individuals who have blood relations, even do not have blood relations unlike domestic servants are called extended family. Due to the family is the smallest unit of society, the health degree of the household or family determines the health degree of the community. Meanwhile, the family health degree is largely determined by a clean and healthy lifestyle (PHBS). Thus, the core of developing a village is to empower families to be able to practice PHBS.

Hypertension or high blood pressure is a disorder in the blood vessels that causes the supply of oxygen and nutrients carried in the blood to be blocked to the body's tissues in need. According to WHO, blood pressure limits are still considered normal are 120-140 mmHg systolic and $80-90 \mathrm{mmHg}$ diastolic. So, someone is called suffering from hypertension if his blood pressure always reads above $140 / 90, \mathrm{mmHg}$. Hypertension is a serious public health problem. If it is not controlled it will develop and cause dangerous complications. The result can be fatal due to frequent complications, for example, stroke, coronary heart disease, and kidney failure.

The cause of hypertension in elderly people is changes in (1) The elasticity of the aortic wall decreases, (2) The heart valve thickens and becomes stiff, (3) The ability of the heart to pump blood decreases, $1 \%$ every year after 20 years the heart's ability to pump blood decreased causing decreased contraction and volume, (4) Loss of blood vessels elasticity. It happens due to the lack of effectiveness of peripheral arteries for oxygenation, (4) Increased peripheral vascular resistance (Paramita et al., 2018; Sandi et al., 2017).

Headache is defined as an unpleasant sensory and emotional experience. Each individual felt pain can vary depending on the threshold and scale of pain felt. It shows the simultaneous and subjective differences in pain for each individual. Pain is usually indicated the pain duration (for example, acute or chronic/persistent) and its causes (for example, nociceptive or neuropathic). It has implications for pain management strategies.

\section{Materials and Methods}

This research is an experimental study with a randomized pretest and posttest control group design in the form of a community trial (Zainudin, 2014; Lestari et al., 2016). The study was conducted in West Selemadeg Subdistrict as a control group and Selemadeg as a treatment group, for three months (August to October

Mustika, I. W., \& Sudiantara, K. (2019). Effects of health promotion with family approaches on blood pressure and headache toward elderly. International Journal of Health Sciences, 3(3), 8-16. https://doi.org/10.29332/ijhs.v3n3.344 
2018). The samples were 590 people. The 295 people are as the control group and 295 is as the treatment group. Random sampling techniques that meet inclusion criteria namely, elderly $60-79$ years old can communicate and do not suffer from infectious diseases. Primary data is obtained directly from respondents by measuring blood pressure using a digital blood pressure meter, and measuring pain perception using a needle. Secondary data is obtained from the village midwife in the form of an elderly notebook about the elderly characteristics (Mustika \& Harini, 2017).

Classification headache is determined as follows, pain is felt in the back of the neck to the head, throbbing or sedentary is categorized into three namely mild, moderate and severe. Blood pressure is described as the ratio of systolic pressure to diastolic pressure, which is measured using mercury tensimeter with hypertension classification.

Table 1

The category of systolic and diastolic

\begin{tabular}{llll}
\hline No & Category & Systolic $(\mathrm{mmHg}$ & Diastolic $(\mathrm{mmHg})$ \\
\hline 1 & Grade I (mild) & $140-159$ & $90-99$ \\
2 & Grade II (moderate) & $160-179$ & $100-109$ \\
3 & Grade III (severe) & $180-209$ & $110-119$ \\
4 & Grade IV (very severe) & $>210$ & $>120$ \\
\hline
\end{tabular}

\section{Results and Discussions}

\subsection{Results}

The caused factors increase in blood pressure and headaches in the elderly namely gender, age, productivity, and occupation. Data description is presented in the following Table 2:

Table 2

The characteristics of research subjects based on treatment and control groups in Selemadeg Subdistrict 2018

\begin{tabular}{llllll}
\hline \multirow{2}{*}{ No } & Characteristics & \multicolumn{2}{c}{ Treatment group } & \multicolumn{2}{c}{ Control group } \\
& F & F & F \\
\hline 1 & Gender & 139 & 47 & 141 & 48 \\
& $\begin{array}{l}\text { a. Male } \\
\text { b. Female }\end{array}$ & 156 & 53 & 154 & 52 \\
2 & $\begin{array}{l}\text { Age } \\
\text { a. } 60-69 \text { years old }\end{array}$ & 209 & 71 & 204 & 69 \\
& $\begin{array}{l}\text { b. } 70-79 \text { years old } \\
3\end{array}$ & 86 & 29 & 91 & 31 \\
& $\begin{array}{l}\text { Productivity } \\
\text { a. Productive }\end{array}$ & 206 & 70 & 212 & 72 \\
b. Unproductive & 89 & 30 & 83 & 28 \\
4 & & & & \\
& $\begin{array}{l}\text { Occupation } \\
\text { a. Farmers }\end{array}$ & 180 & 61 & 171 & 58 \\
b. Trader & 18 & 6 & 103 & 35 \\
& c. Other Workers & 97 & 33 & 21 & 7 \\
\hline
\end{tabular}

Based on Table 2, it can be explained as follows. It is seen from the gender. There are more elderly males than females in the treatment group or the control group. It is seen from the age that most of the 60-69 years old in the treatment group and the control group. Based on productivity in the treatment and control groups, most of the elderly are still productive, only a small proportion are unproductive. Whereas, in the control group it was almost close. Having seen from the occupation in the treatment group and the control group, most of them are farmers. 
Table 3

The descriptive analysis of elder systolic blood pressure in the treatment group

\begin{tabular}{|c|c|c|c|c|c|}
\hline \multirow{2}{*}{ No } & \multirow{2}{*}{ Characteristics } & \multicolumn{2}{|c|}{ Before } & \multicolumn{2}{|c|}{ After } \\
\hline & & Statistics & Std Error & Statistics & Std Error \\
\hline 1 & Mean & 171,92 & .053 & 142,92 & .954 \\
\hline 2 & Median & 170,00 & & 140,00 & \\
\hline 3 & Variance & 83,649 & & 268,480 & \\
\hline 4 & Std Deviation & 9,146 & & 16,385 & \\
\hline 5 & Minimum & 140 & & 100 & \\
\hline 6 & Maximum & 190 & & 180 & \\
\hline 7 & Range & 50 & & 80 & \\
\hline 8 & Interquartile Range & 10,689 & & 20 & \\
\hline 9 & Skewness & -.894 & .142 & -179 & .142 \\
\hline 10 & Kurtosi & .932 & .283 & .042 & .283 \\
\hline
\end{tabular}

Based on Table 2 above it can be seen that the systolic blood pressure in the elderly at the minimum limit before treatment is $140 \mathrm{mmHg}$ and after treatment is $100 \mathrm{mmHg}$. Similar to the maximum limit before being given $190 \mathrm{mmHg}$ treatment and after being given treatment to $180 \mathrm{mmHg}$, this shows that it is still classified as severe hypertension.

Table 4

The descriptive analysis of elderly diastolic blood pressure in the treatment group

\begin{tabular}{llllll}
\hline \multirow{2}{*}{ No } & \multirow{2}{*}{ Characteristics } & \multicolumn{2}{c}{ Before } & \multicolumn{2}{c}{ After } \\
\cline { 2 - 5 } & & Statistics & Std Error & Statistics & Std Error \\
\hline 1 & Mean & 93,63 & .443 & 81,21 & .477 \\
2 & Median & 100,00 & & 80,00 & \\
3 & Variance & 57,888 & & 67,260 & \\
4 & Std Deviation & 7,608 & & 8,201 & \\
5 & Minimum & 80 & & 60 & \\
6 & Maximum & 100 & & 100 & \\
7 & Range & 20 & & 40 & \\
8 & Interquartile Range & 10 & & 10 & .142 \\
9 & Skewness & -.717 & .142 & -.412 & .283 \\
10 & Kurtosi & -.924 & .283 & -.172 & \\
\hline
\end{tabular}

Table 4 shows diastolic blood pressure at the minimum threshold. There is a significant difference. It is before being given a treatment of $80 \mathrm{mmHg}$ and after becoming $60 \mathrm{mmHg}$. For the same maximum limit of 100 $\mathrm{mmHg}$.

Table 5

The descriptive analysis of pain levels in the treatment group

\begin{tabular}{llllll}
\hline \multirow{2}{*}{ No } & \multirow{2}{*}{ Description } & \multicolumn{2}{c}{ Before } & \multicolumn{2}{c}{ After } \\
\cline { 3 - 6 } & & Statistics & Std Error & Statistics & Std Error \\
\hline 1 & Mean & 90,56 & .461 & 76,24 & .461 \\
2 & Median & 90,00 & & 78,00 & \\
3 & Variance & 24,887 & & 62,621 & \\
4 & Std Deviation & 4,989 & & 7,913 & \\
5 & Minimum & 78 & & 56 & \\
\hline
\end{tabular}

Mustika, I. W., \& Sudiantara, K. (2019). Effects of health promotion with family approaches on blood pressure and headache toward elderly. International Journal of Health Sciences, 3(3), 8-16. https://doi.org/10.29332/ijhs.v3n3.344 


\begin{tabular}{llllll}
\hline 6 & Maximum & 110 & & 100 & \\
7 & Range & 32 & & 44 & \\
8 & Interquartile Range & 2 & & 12 & .142 \\
9 & Skewness & 1,279 & .142 & -.138 & .283 \\
10 & Kurtosi & 1,336 & .283 & -.038 & \\
\hline
\end{tabular}

Table 5 shows the level of pain in the treatment group. There is a significant change in the minimum limit of 78 before treatment and 56 after treatment.

Tabel 6

The descriptive analysis of pain level in the control group

\begin{tabular}{llllll}
\hline \multirow{2}{*}{ No } & \multirow{2}{*}{ Description } & \multicolumn{2}{c}{ Before } & \multicolumn{2}{c}{ After } \\
\cline { 3 - 6 } & & Statistics & Std Error & Statistics & Std Error \\
\hline 1 & Mean & 77,53 & .495 & 78,00 & .443 \\
2 & Median & 80,00 & & 80,00 & \\
3 & Variance & 71,778 & & 57,620 & \\
4 & Std Deviation & 8,472 & & 7,591 & \\
5 & Minimum & 56 & & 60 & \\
6 & Maximum & 98 & 98 & \\
7 & Range & 42 & & 38 & \\
8 & Interquartile Range & 8 & & 6 & .142 \\
9 & Skewness & -.599 & .142 & -.495 & .284 \\
10 & Kurtosi & .131 & .284 & -.217 & \\
\hline
\end{tabular}

Based on table 5 above the level of pain in the control group did not get a significant change in numbers between before and after the study.

Table 7

The analysis using Wilcoxon pain levels in the treatment group

\begin{tabular}{|c|c|c|c|c|c|c|}
\hline & & $\mathrm{N}$ & $\begin{array}{l}\text { Mean } \\
\text { Rank }\end{array}$ & $\begin{array}{l}\text { Sum of } \\
\text { Ranks }\end{array}$ & $\mathrm{Z}$ & $\begin{array}{l}\text { Asymp. } \\
\text { Sig. (2 tailed) }\end{array}$ \\
\hline Pain Level Before & Negative Range & $11^{\mathrm{a}}$ & 22,64 & 249,00 & $-14,513^{b}$ & .000 \\
\hline \multirow{3}{*}{ Pain Level After } & Positive Range & & $275^{b}$ & 148,33 & 40792,00 & \\
\hline & Ties & $9 c$ & $9^{c}$ & & & \\
\hline & Total & 295 & & & & \\
\hline
\end{tabular}

Based on Table 7, it can be seen that the p-value $<0.05$. therefore, there is a significant difference in the level of pain between before and after treatment.

Table 8

The analysis using Wilcoxon systolic blood pressure in the treatment group

\begin{tabular}{lllllll}
\hline & & $\mathrm{N}$ & $\begin{array}{l}\text { Mean } \\
\text { Rank }\end{array}$ & $\begin{array}{l}\text { Sum of } \\
\text { Ranks }\end{array}$ & Z & $\begin{array}{l}\text { Asymp. } \\
\text { Sig. (2-tailed) }\end{array}$ \\
\hline Systolic Before & Negative Range & $6^{\mathrm{a}}$ & 72,42 & 434,50 & & $-14,360^{\mathrm{b}}$ \\
Systolic After & $\begin{array}{l}\text { Positive Range } \\
\text { Ties } \\
\text { Total }\end{array}$ & $\begin{array}{l}278^{\mathrm{b}} \\
11 \mathrm{c}\end{array}$ & $\begin{array}{l}144,01 \\
9^{\mathrm{c}}\end{array}$ & 40035,50 & & \\
& 295 & & & & \\
\hline
\end{tabular}


Based on Table 8, it can be seen systolic blood pressure in the treatment group $\mathrm{p}<0.05$. therefore, there are significant differences before and after treatment.

Table 9

The analysis using Wilcoxon diastolic blood pressure in the treatment group

\begin{tabular}{|c|c|c|c|c|c|c|}
\hline & & $\mathrm{N}$ & $\begin{array}{l}\text { Mean } \\
\text { Rank }\end{array}$ & $\begin{array}{l}\text { Sum of } \\
\text { Ranks }\end{array}$ & Z & $\begin{array}{l}\text { Asymp. } \\
\text { Sig. (2-tailed) }\end{array}$ \\
\hline \multirow{5}{*}{$\begin{array}{l}\text { Pain Levels } \\
\text { Before } \\
\text { Pain Level } \\
\text { After }\end{array}$} & Negative Range & $13^{a}$ & 66,00 & 858,00 & \multirow{5}{*}{$-13,185^{b}$} & \multirow{5}{*}{.000} \\
\hline & & & & & & \\
\hline & Positive Range & $235^{b}$ & 127,74 & 30018,00 & & \\
\hline & Ties & $47 c$ & \multirow{2}{*}{\multicolumn{2}{|c|}{$9 \mathrm{c}$}} & & \\
\hline & Total & 295 & & & & \\
\hline
\end{tabular}

Based on Table 9, the p-value is $<0.05$. therefore, there are significant differences in diastolic blood pressure before and after treatment.

\subsection{Discussions}

1) Elderly blood pressure before and after being given a health promotion with a family approach

According to WHO (World Health Organization), blood pressure limits are still considered normal are 120$140 \mathrm{mmHg}$ systolic and $80-90 \mathrm{mmHg}$ diastolic. The hypertension cause in the elderly is more due to decrease aortic wall elasticity, heart valves thicken, and become stiff, the heart ability to pump blood decreases $1 \%$ every year after 20 years the heart's ability to pump blood decreases causing decreased contraction and volume, loss of elasticity of blood vessels, and increased peripheral vascular resistance. Applying a healthy lifestyle is very important in preventing hypertension and prevention with regular medical check-ups.

a) Overview of hypertension based on gender

The study results of the hypertension number are more in males. Rahajeng (2009), also mentioned that high cases of hypertension in the male may be caused by unhealthy behavior (smoking and alcohol consumption habits), depression and low work status, feeling uncomfortable about work, and unemployment. The high prevalence of hypertension in females over 45-55 years old was found from research conducted by Kumar et al., (2005) and Bustan (2005).

b) Overview of hypertension based on age Unlike a person ages, the risk of developing high blood pressure increases.

c) Overview of hypertension with productivity Lack of physical activity increases the risk of high blood pressure due to the increased risk of being fat. Inactive people tend to have faster heart rates and their heart muscles have to work harder with each contraction, the harder and often the heart has to pump the higher forces the arteries.

d) Overview of hypertension with occupation

Work is seen more in terms of the likelihood of specific exposure and the level or degree of exposure, as well as the magnitude of risk according to the work nature, work environment, and socioeconomics in certain occupations (Nasry Noor, 2008; Anjana \& Chacko, 2014). There are also various things may be closely related to the work nature, for example, gender, age, marital status, and education level. It also greatly affects the level of worker's health.

2) Research results on health promotion of headache level in the elderly before and after treatment

Headaches generally are often felt and are easily removed in a simple way for mild pain. The elderly with a high risk of various diseases are easier to attack. Due to it is very appropriate preventive and promotive measures. It is simpler, easier and cheaper. If we compare it with curative measures.

Some terms can do to be healthy (1) exercise regularly and take time for entertainment. (2) adequate rest, balanced menu, and reduce stress. (3) Fish consumption, in addition to being good for intelligence, it

Mustika, I. W., \& Sudiantara, K. (2019). Effects of health promotion with family approaches on blood pressure and headache toward elderly. International Journal of Health Sciences, 3(3), 8-16. https://doi.org/10.29332/ijhs.v3n3.344 
is also effective in reducing headaches. Rich fish with high omega 3 content, good for brain intelligence, preventing brain cancer to eliminate headaches.

3) Effect of Health Promotion with a family approach to blood pressure and reduction headache level in the elderly before being given treatment

Mann Whitney test was used to test two unpaired groups. The unpaired sample group is the treatment group and the control group. An assessment of the effect of providing health promotion with a family approach to the level of pain and blood pressure in the elderly was carried out using different tests in the two groups type. Mann Whitney test results on the pain level data of the treatment and control groups after the intervention obtained $\mathrm{p}$-value $=0.0001$. Mann Whitney test results on the systolic blood pressure data of the treatment and control groups after the intervention got p-value $=0.0001$. Mann Whitney test results on the diastolic blood pressure data of the treatment and control groups after the intervention obtained $p$-value $=0,0001$. Based on these results, it can be seen the significance $p$-value $<0.05$, then there are significant differences in the treatment group and the control group after being given treatment in the form of health promotion with a family approach to the level of pain and blood pressure in the elderly. The description shows the p-value $<0.05$. Therefore, the hypothesis of this study or Ha is accepted. There is an effect of health promotion with a family approach to the reduction of pain and blood pressure in the elderly in Selemadeg Subdistrict, Tabanan Regency.

The family is the smallest scope in a community group. The health promotion carried out must be more specific too. Health education is also expected to be more effective. Due to it focuses on one family as a target.

Health promotion in the current study is an activity or effort to convey health messages to the elderly. The message is expected the elderly with a family approach can gain knowledge about health which includes the understanding of hypertension, causes of hypertension, hypertension symptoms, prevention of hypertension, and hypertension management. Likewise, regarding pain namely, the location of pain, the onset of pain, the nature of pain, the intensity of pain, and management is conducted, if there is a pain. The knowledge is ultimately expected to influence the behavior of the elderly.

On health promotion, the role of partnerships is emphasized even more. It is based on equality, transparency, and mutual benefit.

\section{Conclusion}

Based on the elderly characteristics in the treatment group, it was found. The number of elderly females was 156 people (53\%) and male 139 people (47\%). Having seen from the age of 209 (71\%) between 60-69 years old and 86 people (29\%) between 70-79 years old. The elderly are still productive 206 people (70\%) and unproductive 89 people (30\%) and most of the elderly work as farmers 180 people (61\%). On the treatment group before and after the intervention was obtained the $p$-value $=0.0001$ in systolic and diastolic pressure data as well as the headache level. Due to the p-value $<0.05$, it can be seen. There are significant differences before and after health promotion with a family approach. On the control group before and after the intervention was obtained the p-value $=0.0001$ for pain level data, but the systolic and diastolic blood pressure measurement data was found to be $\mathrm{p}>0.05$. Therefore, data in the control group were not significant differences before and after the intervention was given.

\section{Suggestion}

In order to reduce the number of non-communicable diseases in the elderly, especially, hypertension and headaches, health workers should encourage the healthy promotion of living community movement (GERMAS) through health counseling and distributing brochures to the public including. A balanced and exercise menu, thus, healthy elderly are realized prosperous.

\section{Acknowledgments}

We thank the editor of IJHS for their valuable time, support and advice. 
References

Adnani, H., Subiyanto, A., Hanim, D., \& Sulaeman, E. S. (2018). Health promotion in clean and healthy behavior programs in traditional markets. International Research Journal of Management, IT and Social Sciences, 5(4), 46-52. https://doi.org/10.21744/irjmis.v5n4.251

Anjana, A., \& Chacko, A. T. (2014). Prevalence and correlates of functional limitation among elderly in Kerala. International Research Journal of Management, IT and Social Sciences, 1(1), 22-29.

Bustan, D., Flaisher, A., Grumberg, O., Kupferman, O., \& Vardi, M. Y. (2005, October). Regular vacuity. In Advanced Research Working Conference on Correct Hardware Design and Verification Methods (pp. 191206). Springer, Berlin, Heidelberg. https://doi.org/10.1007/11560548_16

Kumar, K., Gupta, S. C., Baidoo, S. K., Chander, Y., \& Rosen, C. J. (2005). Antibiotic uptake by plants from soil fertilized with animal manure. Journal of environmental quality, 34(6), 2082-2085.

Lestari, A. S., Adiputra, N., Manuaba, I. A., \& Sutjana, I. D. P. (2016). Access to personal hygiene improves the quality of life at elderly hostels. International Research Journal of Engineering, IT \& Scientific Research, 2(11), 22-28.

Mustika, I. W., \& Harini, G. A. (2017). Increasing education of family support for decreasing depression level towards elderly. International Journal of Health Sciences, 1(3), https://doi.org/10.21744/ijhs.v1i3.46

Nasry Noor, N. (2008). Epidemiologi. Jakarta: PT. Rineka Cipta.

Paramita, D. P., Adiatmika, I., Kuswardhani, T., \& Mustika, I. W. (2018). Physiological and psychosocial change and the need of health intervention model for elderly. International Journal of Health Sciences, 2(2), 61-67. https://doi.org/10.29332/ijhs.v2n2.160

Rahajeng, E., \& Tuminah, S. (2009). Prevalensi hipertensi dan determinannya di Indonesia. Majalah Kedokteran Indonesia, 59(12), 580-587.

Sandi, I. N., Ardana, A. G., Parwata, I. M. Y., \& Teresna, I. W. (2017). Effect of relative humidity on expenditure of body fluids and blood pressure when exercise. International Research Journal of Engineering, IT \& Scientific Research, 3(2), 114-122.

Sulaeman, R., Muhasidah, -, Purnamawati, D., Zulkifli, -, Jafar, S., \& Suiraoka, I. (2018). Progressive muscle relaxation using video aids reduces blood pressure of hypertension patients. International Journal of Health Sciences, 2(3), 33-42. https://doi.org/10.29332/ijhs.v2n3.214

Zainudin, E. S., Yan, L. H., Haniffah, W. H., Jawaid, M., \& Alothman, O. Y. (2014). Effect of coir fiber loading on mechanical and morphological properties of oil palm fibers reinforced polypropylene composites. Polymer Composites, 35(7), 1418-1425. https://doi.org/10.1002/pc.22794

Mustika, I. W., \& Sudiantara, K. (2019). Effects of health promotion with family approaches on blood pressure and headache toward elderly. International Journal of Health Sciences, 3(3), 8-16. https://doi.org/10.29332/ijhs.v3n3.344 


\section{Biography of Authors}

\begin{tabular}{|l|l||} 
Drs I Wayan Mustika, S.Kep., Ns., M.Kes. is an associate professor. He was born in \\
Megati, on August 11th, 1965. He lives at Jalan Sanitasi No. 1 Sidakarya, Denpasar. \\
He teaches society health nursing, family care, gerontic treatment, health tourism, \\
health promotion. He completed his bachelor degree in IKIP PGRI Bali in 1991, \\
Nursing Education 2008, as well as the Academy of Nursing in Padjajaran Bandung \\
2000 than following in Education Profession of Ners in 2009. He finished his \\
Master Degree in AKK UNAIR Surabaya in 2003. \\
Email: wayankayunan@gmail.com
\end{tabular}

